\title{
Population structure and reproduction of three sympatric species of hermit crabs in the north-western Mediterranean
}

\author{
E. Macpherson* and N. Raventos \\ Centro de Estudios Avanzados de Blanes (CSIC), C. acc. Cala Sant Francesc 14, \\ 17300 Blanes, Girona, Spain. *Corresponding author, e-mail: macpherson@ceab.csic.es
}

\begin{abstract}
The populations of three sympatric hermit crabs, Pagurus excavatus, Anapagurus alboranensis and Anapagurus petiti were studied in a shallow (15-25 m) sandy area in the north-western Mediterranean. Seasonal abundance, seasonal size frequency, sex ratio and reproductive periods were examined. Pagurus excavatus was the largest and most abundant species in the zone. Pagarus excavatus and Anapagarus alboranensis are sexually dimorphic in relation to size, with males reaching larger sizes than females. However, the males and females of Anapagurus petiti reach similar large sizes. Anapagurus petiti has a sex ratio that is female biased, whereas A. alboranensis and P. excavatus are 1:1. Anapagurus petiti showed a higher reproductive activity during warmer seasons, while in A. alboranensis the proportion of ovigerous females was high throughout the year, with a minimum in autumn. The activity and clutch size of $P$. excavatus decreased during summer.
\end{abstract}

\section{INTRODUCTION}

Hermit crabs are one of the most diverse groups of crustacean decapods and are a crucial element of the littoral benthic fauna in temperate waters (Abelló et al., 2002). This group of decapods is well represented in European waters, and about 30 species are commonly found in the Mediterranean Sea (Ingle, 1993). Numerous studies have examined several biological aspects of hermit crabs, such as growth, reproduction, use of habitats and gastropod shells and behaviour (e.g. Bertness, 1981; Manjón-Cabeza \& García-Raso, 1999a,b; Turra \& Leite, 2000 and references cited therein). Furthermore, the population structure and the reproductive period of many hermit crabs have been summarized (Turra \& Leite, 2000). However, these studies are scarce for European species, particularly for sympatric populations (e.g. Manjón-Cabeza \& García-Raso, 1999a,b).

European waters host 12 species of the genus Pagurus Fabricius, 1775, and 12 species of the genus Anapagurus Henderson, 1887 (Ingle, 1993; Garcia-Gomez, 1994). Three species of hermit crab, Anapagurus alboranensis Garcia-Gomez, 1994, A. petiti Dechance \& Forest, 1962 and Pagurus excavatus (Herbst, 1791) are quite common in shallow soft bottoms in the Mediterranean Sea. Although the taxonomy of these species is well documented, their biology is practically unknown (but see Manjón-Cabeza \& García-Raso, 1999b; Mura \& Cau, 2002). Here we describe the population structure of these three species in the north-western Mediterranean and study their seasonal abundance, seasonal size frequency, sex ratio and reproductive periods.

\section{MATERIALS AND METHODS}

This study was undertaken in the littoral region of Blanes, Spain (north-western Mediterranean, $41^{\circ} 40^{\prime} 09^{\prime \prime} \mathrm{N}$ $02^{\circ} 41^{\prime} 09^{\prime \prime} \mathrm{E}$ ). The sea bottoms analysed were at a depth of $15-25 \mathrm{~m}$. This is a low slope sandy area, usually composed of medium sand sediments, 250 to $500 \mu \mathrm{m}$.
Samples were taken monthly from February 2002 to January 2003. Three sites, separated by $1 \mathrm{~km}$, were selected for sampling. Individuals of Pagurus excavatus and large specimens of Anapagurus run very fast and escaped easily from small commercial trawls (personal observations). Therefore, the use of traditional sampling techniques, e.g. trawls, dredges (see references cited above) may bias the abundance and size distributions of these species. For these reasons we used visual censuses, following visual monitoring techniques commonly used in fish studies (e.g. Macpherson et al., 2002) and hand nets. Sixteen visual transects measuring $1 \times 50 \mathrm{~m}$ were monitored monthly at each site. We used a small hand net $(30 \times 30 \mathrm{~cm}, 2-\mathrm{mm}$ mesh size) to trawl the bottom along each transect to collect specimens. Two SCUBA divers performed the monitoring in this study. Each species was easily distinguishable during diving because of their colour pattern and size. The three species occasionally buried their bodies in the sand (usually P. excavatus), however, they were easily detected with the hand net. All individuals collected at the three sites in a given month were pooled to yield overall monthly totals. A representative number of individuals for each species and month was used to estimate population structure and biological data.

Hermit crabs were taken to the laboratory, where they were removed from their shells, sexed (males, females and ovigerous females) and measured (shield length, $\mathrm{mm}$ ). The cephalothoracic shield length (shield length=from the tip of the rostrum to the groove at the posterior edge) was measured using an ocular micrometer. This is the most frequently used structure to define size in hermit crabs (Fransozo \& Mantelatto, 1998; Manjon-Cabeza \& Garcia-Raso, 1999a,b; Turra \& Leite, 2000). The specimens were grouped in $0.5 \mathrm{~mm}$ size-class intervals for the two species of Anapagurus and in $1 \mathrm{~mm}$ intervals for $P$. excavatus. Reproductive activity was estimated as the percentage of females that carried eggs relative to the total number of females collected. Pleopods with attached eggs were removed the same day of capture to estimate 
female fecundity (number of eggs per clutch) and eggs counted to avoid biases due to fixation. If the number of eggs was relatively small $(<500)$, they were counted. In larger clutches, eggs were detached from pleopods and weighed to the nearest $0.1 \mathrm{mg}$. Four sub-samples were then weighed to the nearest $0.1 \mathrm{mg}$, and the eggs in each were counted, and the total number of eggs was obtained proportionally for each sub-sample. The total number of eggs per ovigerous female was calculated using the average of the four sub-samples. Those ovigerous females with broken abdomens were not considered in the estimation of clutch sizes.

The distribution frequency of the population of each species was analysed with analysis of variance (ANOVA), followed by Tukey unequal $\mathrm{N}$ honestly significant difference test for post hoc pair-wise comparisons. When necessary, data were natural log transformed to improve homogeneity of variance. A $\chi^{2}$-test was applied to evaluate the overall sex ratio and by size. To determine the size of mature females, the percentage of ovigerous females was calculated. We estimated the size at which the frequency of ovigerous females was over $50 \%$ as the maturity size. Because hermit crabs with a reproductive period that
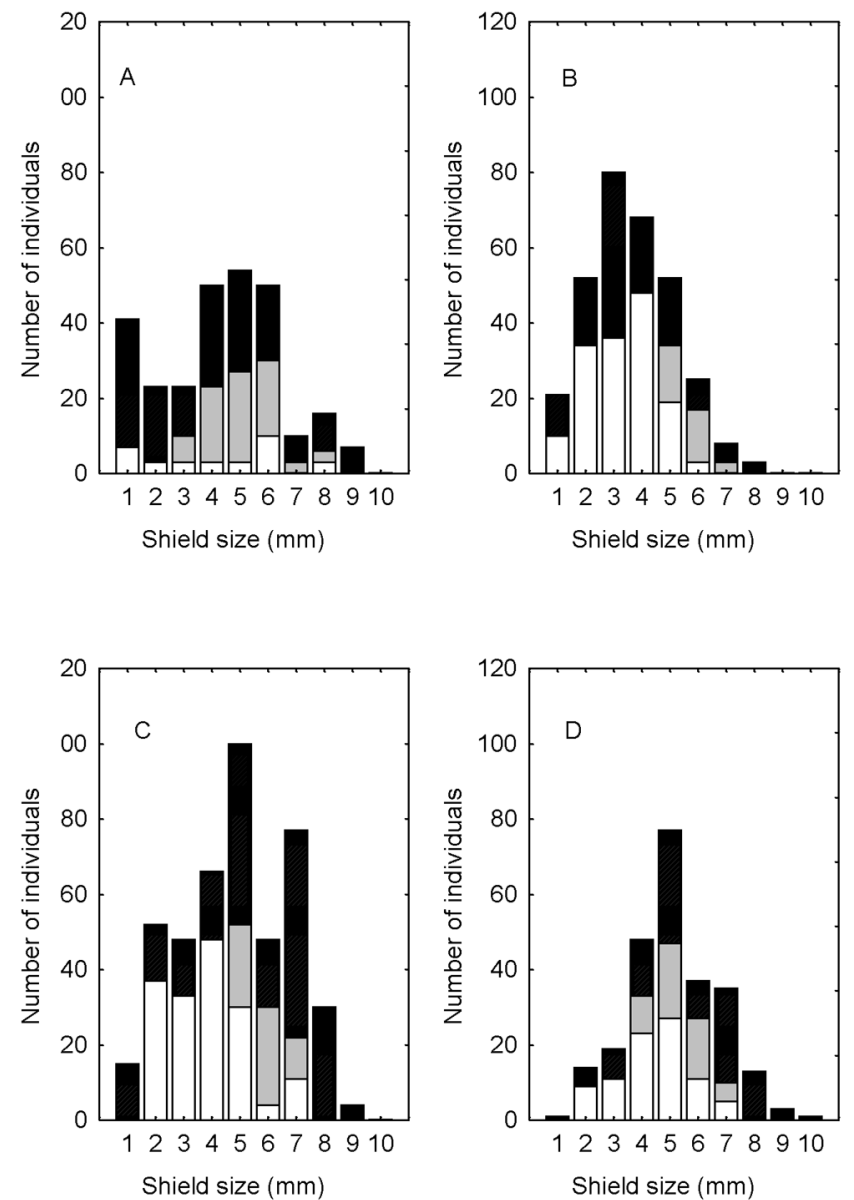

Figure 1. Seasonal size-frequency distribution (shield length, mm) of males, ovigerous females and females of Pagurus excavatus at Blanes, Spain (north-western Mediterranean Sea). Number of specimens (N) are from all individuals collected at the three sampling sites in a given season. (A) Winter $(\mathrm{N}=274)$; (B) spring $(\mathrm{N}=309)$; $(\mathrm{C})$ summer $(\mathrm{N}=440)$; (D) autumn $(\mathrm{N}=248)$. Black bars, males; grey bars, ovigerous females; white bars, non-ovigerous females. covers more than one season (e.g. Pagurus excavatus and Anapagurus alboranensis, see Results) can show differences in fecundity (Wada et al., 2000), here we compared the number of eggs and size at maturity between seasons by one-way analysis of covariance (ANCOVA) and using the shield length as covariate.

\section{RESULTS}

A total of 3713 Pagurus excavatus, 1843 Anapagurus alboranensis and $408 \mathrm{~A}$. petiti individuals were monitored in the area over the study period. We used 1271, 615 and 138 individuals, respectively, for population structure and reproductive biology analyses.

Individuals of $P$. excavatus (mean $=4.52 \mathrm{~mm}, \mathrm{SD}=1.78$, range $=1.2-11.0 \mathrm{~mm}$ ) were, on average, larger than those of $A$. petiti (mean $=1.99 \mathrm{~mm}, \quad \mathrm{SD}=0.51$, range $=0.9-$ $3.1 \mathrm{~mm}$ ) and $A$. alboranensis (mean $=1.53 \mathrm{~mm}, \mathrm{SD}=0.26$, range $=0.7-2.4 \mathrm{~mm}) \quad$ (ANOVA, Tukey test, $P<0.0001$ ). Individuals of $A$. petiti were also, on average, larger than those of $A$. alboranensis (ANOVA, Tukey test, $P<0.02$ ).

Population density for the three species peaked in summer (Figures 1-3). The population sex ratio was
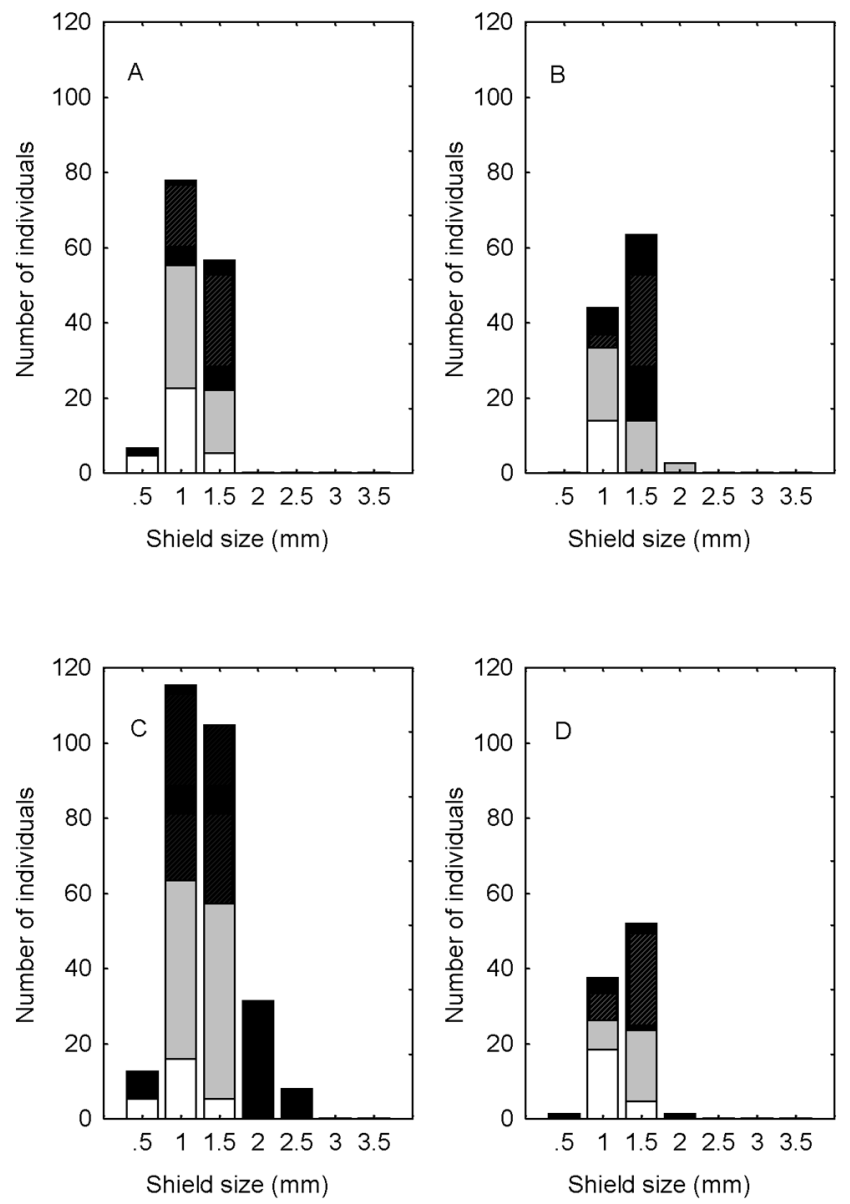

Figure 2. Seasonal size-frequency distribution (shield length, $\mathrm{mm}$ ) of males, ovigerous females and females of Anapagurus alboranensis at Blanes, Spain (north-western Mediterranean Sea). Number of specimens (N) are from all individuals collected at the three sampling sites in a given season. (A) Winter $(\mathrm{N}=141)$; (B) spring $(\mathrm{N}=110)$; (C) summer $(\mathrm{N}=272)$; (D) autumn $(\mathrm{N}=92)$. Black bars, males; grey bars, ovigerous females; white bars, non-ovigerous females. 

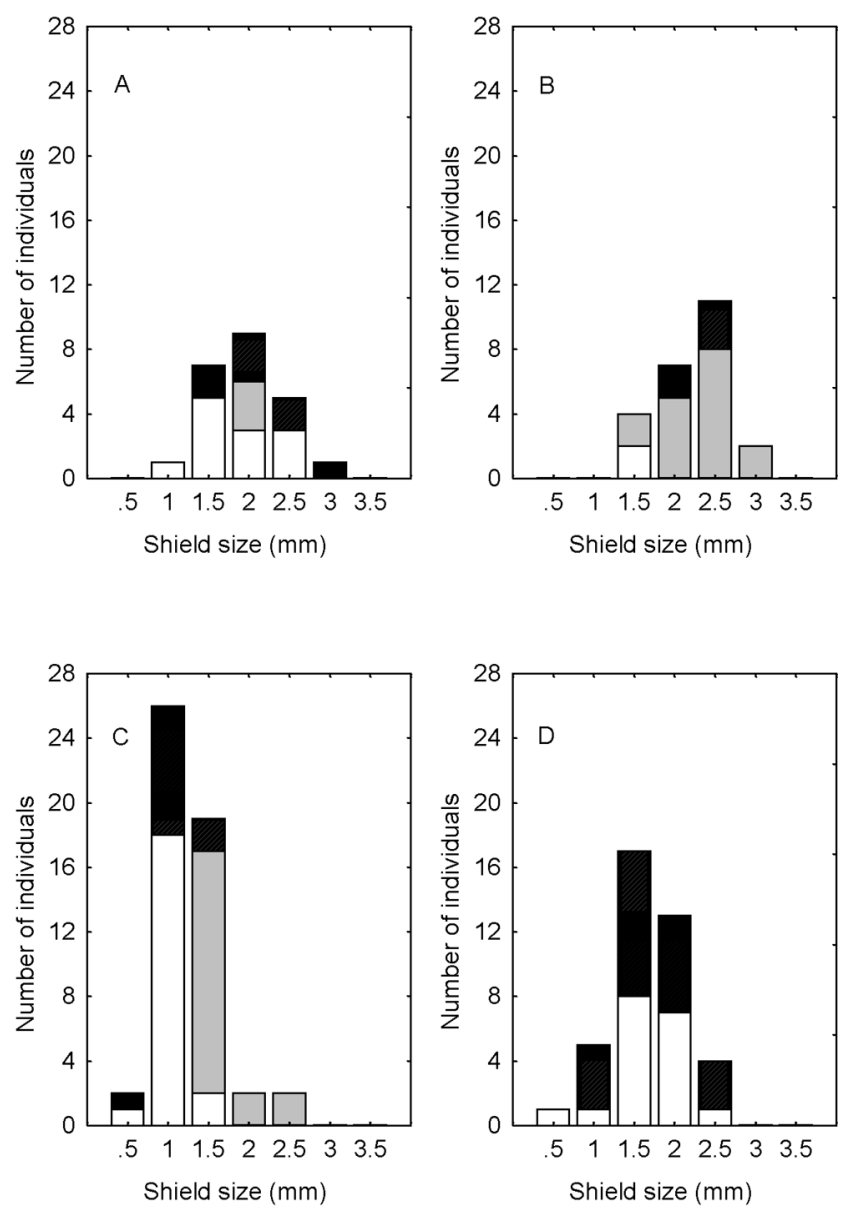

Figure 3. Seasonal size-frequency distribution (shield length, $\mathrm{mm}$ ) of males, ovigerous females and females of Anapagurus petiti at Blanes, Spain (north-western Mediterranean Sea). Number of specimens (N) are from all individuals collected at the three sampling sites in a given season. (A) Winter $(\mathrm{N}=23)$; (B) spring $(\mathrm{N}=24)$; ( $\mathrm{C})$ summer $(\mathrm{N}=51)$; (D) autumn $(\mathrm{N}=48)$. Black bars, males; grey bars, ovigerous females; white bars, non-ovigerous females.

slightly skewed for females in the three species (Pagurus excavatus (653 females vs 618 males, Anapagurus alboranensis 308 vs $307, A$. petiti 91 vs 47), however, the difference was only significant in $A$. petiti $\left(\chi^{2}\right.$-test, $\left.P=0.007\right)$. The population sex ratio changed in several seasons in $P$. excavatus and $A$. petiti (Table 1). The sex ratio was related to size in $P$. excavatus and $A$. alboranensis (differences were non-significant in $A$. petiti). Females were more frequent at intermediate sizes but were significantly less abundant at larger sizes in both species $\left(\chi^{2}\right.$-test, $\left.P<0.05\right)$. Males were also more frequent than females at the smallest size-class in $P$. excavatus. The seasonal analysis of size structure in Pagurus excavatus showed a bimodal distribution in winter, with peaks in the smallest $(>1 \mathrm{~mm})$ and intermediate $(4-6 \mathrm{~mm})$ size-classes. Intermediate and large size-classes were more numerous in summer (Figure 1). The mean shield lengths among seasons were significantly different (ANOVA, $F=109.159$, df=3, $P<0.0001$ ), decreasing from autumn to summer (all pair-wise post hoc comparisons, $P<0.0001)$. Except in winter, males were more abundant in the largest $(>7 \mathrm{~mm})$ and smallest $(<1 \mathrm{~mm})$ sizes, whereas females were more common at

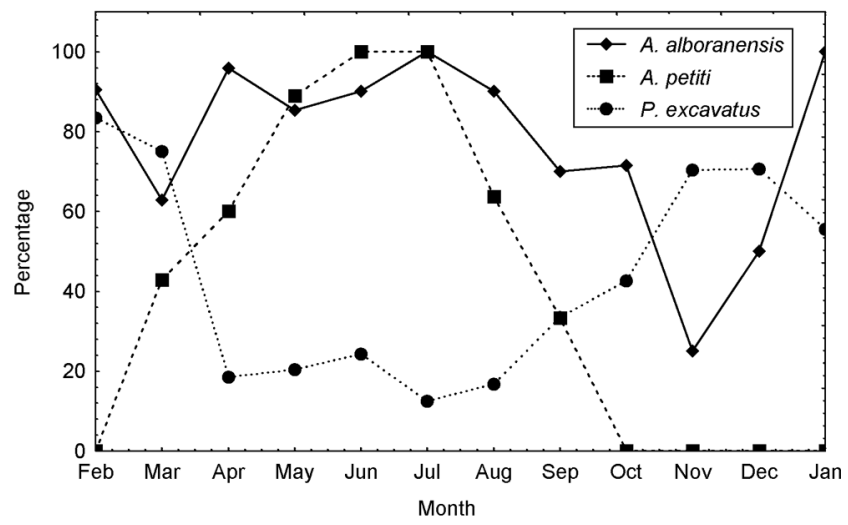

Figure 4. Reproductive activity of Anapagurus alboranensis, A. petiti and Pagurus excavatus indicated by the frequency of ovigerous females through the year, at Blanes, Spain (northwestern Mediterranean Sea).

intermediate sizes (Figure 1). Anapagurus alboranensis showed an unimodal distribution in all seasons (Figure 2). Mean sizes did not differ among seasons (ANOVA, $F=2.677, \mathrm{df}=3, P=0.06)$ and post hoc comparisons were always non-significant $(P>0.2$ in all cases). The smallest specimens were collected in winter and summer, with no clear differences in the sex ratio. The largest individuals $(>2 \mathrm{~mm})$ were always males and they were usually observed in summer (Figure 2). The size structure of $A$. petiti showed significant differences among seasons (ANOVA, $F=12.488$, df=3, $P<0.0001$ ). The mean sizes of the population were similar during winter, spring and autumm (Tukey test, $P>0.20$ in all comparisons), being significantly smaller in summer (Tukey test, $P<0.001$ ), when individuals smaller than $1 \mathrm{~mm}$ were clearly more abundant (Figure 3).

The smallest size-class individuals of Pagurus excavatus occurred mainly in winter, spring and summer, whereas in Anapagurus alboranensis these individuals appeared in summer and winter and in $A$. petiti during summer and autumn.

A high proportion of ovigerous females was observed for $P$. excavatus in autumn and winter (November-March), decreasing in spring and summer (Figure 4). Anapagurus alboranensis showed a high proportion of ovigerous females $(>60 \%)$ throughout the year, except in autumn, when a minimum was observed (November). Ovigerous females of $A$. petiti were more abundant in spring and early summer (April-July), (Figure 4). The number of eggs in P. excavatus varied from 34 to 1670 , and a significant correlation between clutch size and female size was observed (Figure 5). Furthermore, the number of eggs per female was higher in autumn and winter than in spring and summer (ANCOVA $F=6.551, \quad \mathrm{df}=1, \quad P<0.002$ ). The relationships were as follows: autumn/winter, $\mathrm{N}=62$, eggs $=-1131.35+290.87$ shield length $(\mathrm{SL}), r^{2}=0.40$, $P<0.0001 ; \quad$ spring, $\quad \mathrm{N}=32$, eggs $=-499.0+127.27 \quad \mathrm{SL}$, $r^{2}=0.35, P<0.001$. In A. alboranensis, the number of eggs per clutch varied from 7 to 236 and from 14 to 428 in $A$. petiti. Female size was positively correlated with clutch size in the two species of Anapagurus, although in A. alboranensis this relationship differed significantly in autumn/winter 
Table 1. Mean size (X, cephalothoracic shield length, in $\mathrm{mm}$ ), standard deviation (SD), and abundance ( $\mathcal{N})$ by sex and season of Anapagurus alboranensis, A. petiti and Pagurus excavatus. The relationship 1:1 between sexes was evaluated using a $\chi^{2}$-test (*, $\mathrm{P} \leqslant 0.05$; n.s., non-significant).

\begin{tabular}{|c|c|c|c|c|c|c|c|c|c|c|c|c|c|}
\hline & & \multicolumn{4}{|c|}{ Anapagurus alboranensis } & \multicolumn{4}{|c|}{ Anapagurus petiti } & \multicolumn{4}{|c|}{ Pagurus excavatus } \\
\hline & & $\mathrm{F}$ & Fov & M & $\mathrm{M} / \mathrm{F}$ & $\mathrm{F}$ & Fov & M & $\mathrm{M} / \mathrm{F}$ & $\mathrm{F}$ & Fov & M & $\mathrm{M} / \mathrm{F}$ \\
\hline Winter & $\begin{array}{l}\mathrm{N} \\
\mathrm{X} \\
\mathrm{SD}\end{array}$ & $\begin{array}{c}33 \\
1.36 \\
0.33\end{array}$ & $\begin{array}{c}49 \\
1.50 \\
0.19\end{array}$ & $\begin{array}{c}59 \\
1.52 \\
0.28\end{array}$ & $1 / 1.4^{\text {n.s. }}$ & $\begin{array}{c}12 \\
2.23 \\
0.08\end{array}$ & $\begin{array}{c}3 \\
2.32 \\
0.48\end{array}$ & $\begin{array}{c}8 \\
2.64 \\
0.38\end{array}$ & $1 / 1.9^{\text {n.s. }}$ & $\begin{array}{c}32 \\
4.66 \\
2.19\end{array}$ & $\begin{array}{c}77 \\
5.59 \\
1.17\end{array}$ & $\begin{array}{l}165 \\
4.53 \\
2.26\end{array}$ & $1 / 0.7 *$ \\
\hline Spring & $\begin{array}{l}\mathrm{N} \\
\mathrm{X} \\
\mathrm{SD}\end{array}$ & $\begin{array}{c}14 \\
1.34 \\
0.16\end{array}$ & $\begin{array}{c}36 \\
1.48 \\
0.15\end{array}$ & $\begin{array}{c}60 \\
1.63 \\
0.19\end{array}$ & $1 / 0.8^{\text {n.s. }}$ & $\begin{array}{c}2 \\
1.78 \\
0.21\end{array}$ & $\begin{array}{c}17 \\
2.43 \\
0.38\end{array}$ & $\begin{array}{c}5 \\
2.62 \\
0.23\end{array}$ & $1 / 3.3 *$ & $\begin{array}{l}150 \\
3.73 \\
1.18\end{array}$ & $\begin{array}{c}35 \\
5.94 \\
0.96\end{array}$ & $\begin{array}{c}124 \\
4.12 \\
1.58\end{array}$ & $1 / 1.5^{*}$ \\
\hline Summer & $\begin{array}{l}\mathrm{N} \\
\mathrm{X} \\
\mathrm{SD}\end{array}$ & $\begin{array}{c}21 \\
1.34 \\
0.27\end{array}$ & $\begin{array}{l}105 \\
1.48 \\
0.24\end{array}$ & $\begin{array}{l}146 \\
1.52 \\
0.34\end{array}$ & $1 / 0.9^{\text {n.s. }}$ & $\begin{array}{c}20 \\
1.24 \\
0.07\end{array}$ & $\begin{array}{c}19 \\
1.89 \\
0.38\end{array}$ & $\begin{array}{c}12 \\
1.33 \\
0.22\end{array}$ & $1 / 3.2 *$ & $\begin{array}{l}178 \\
4.21 \\
1.38\end{array}$ & $\begin{array}{c}44 \\
5.95 \\
0.88\end{array}$ & $\begin{array}{l}218 \\
5.83 \\
2.10\end{array}$ & $1 / 1^{\text {n.s. }}$ \\
\hline Autumn & $\begin{array}{l}\mathrm{N} \\
\mathrm{X} \\
\mathrm{SD}\end{array}$ & $\begin{array}{c}23 \\
1.43 \\
0.16\end{array}$ & $\begin{array}{c}27 \\
1.58 \\
0.17\end{array}$ & $\begin{array}{c}42 \\
1.64 \\
0.30\end{array}$ & $1 / 1.2^{\text {n.s. }}$ & $\begin{array}{c}18 \\
2.00 \\
0.42\end{array}$ & $\begin{array}{l}0 \\
0 \\
0\end{array}$ & $\begin{array}{c}22 \\
2.03 \\
0.46\end{array}$ & $1 / 0.8^{\text {n.s. }}$ & $\begin{array}{c}86 \\
4.86 \\
1.21\end{array}$ & $\begin{array}{c}51 \\
5.87 \\
1.86\end{array}$ & $\begin{array}{l}111 \\
6.02 \\
1.84\end{array}$ & $1 / 1.2^{\text {n.s. }}$ \\
\hline Total & $\begin{array}{l}\mathrm{N} \\
\mathrm{X} \\
\mathrm{SD}\end{array}$ & $\begin{array}{c}91 \\
1.41 \\
0.28\end{array}$ & $\begin{array}{l}217 \\
1.51 \\
0.20\end{array}$ & $\begin{array}{l}307 \\
1.57 \\
0.28\end{array}$ & $1 / 1^{\text {n.s. }}$ & $\begin{array}{c}52 \\
1.92 \\
0.48\end{array}$ & $\begin{array}{c}39 \\
2.05 \\
0.69\end{array}$ & $\begin{array}{c}47 \\
2.12 \\
0.33\end{array}$ & $1 / 1.9 *$ & $\begin{array}{l}446 \\
3.85 \\
1.29\end{array}$ & $\begin{array}{l}207 \\
5.79 \\
0.90\end{array}$ & $\begin{array}{l}618 \\
4.79 \\
2.08\end{array}$ & $1 / 0.9^{\text {n.s. }}$ \\
\hline
\end{tabular}

F, non-ovigerous females; Fov, ovigerous females; M, males; M/F, males-females ratio.
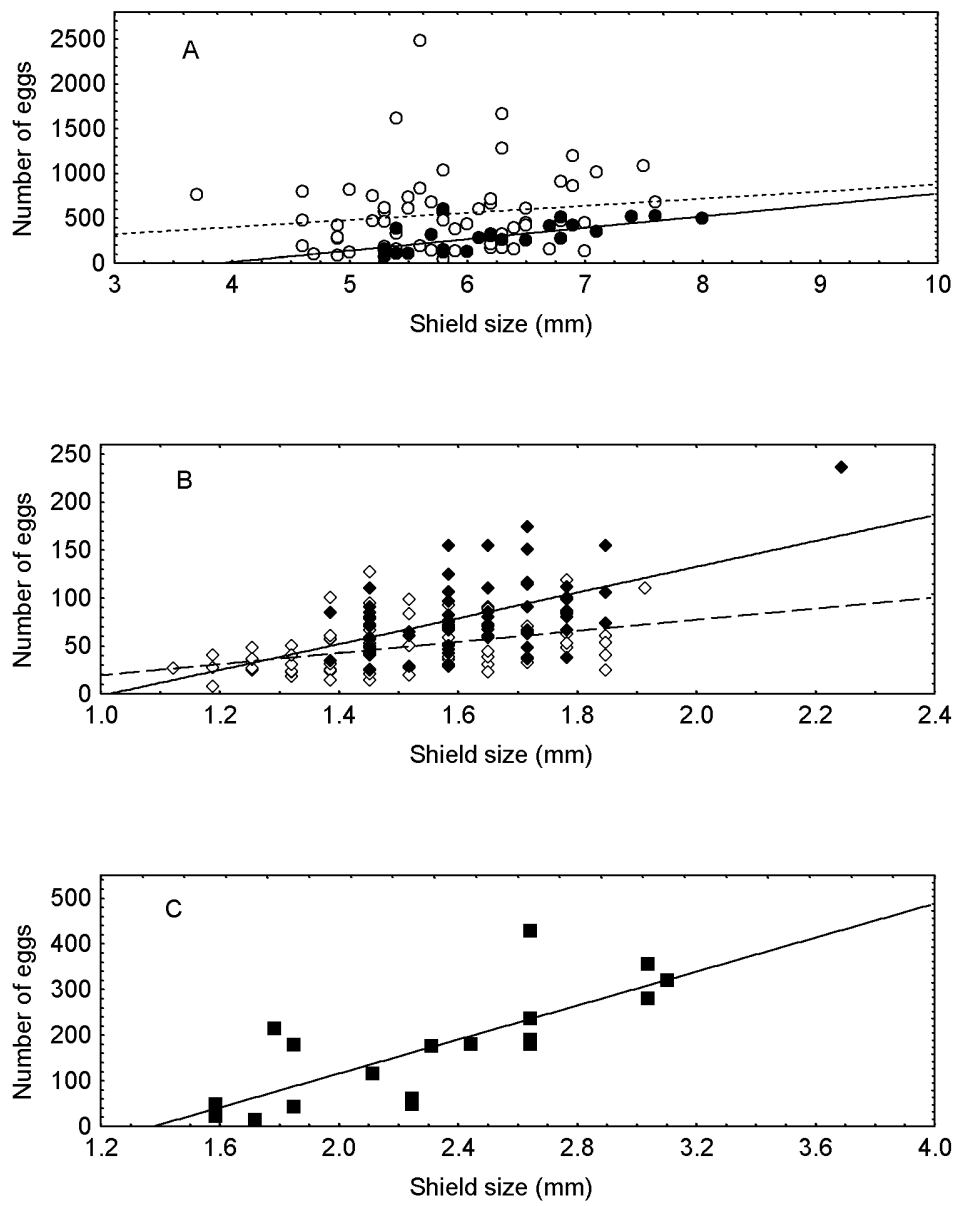

Figure 5. Relationship between female size (shield length, $\mathrm{mm}$ ) and clutch size (number of eggs) in (A) Pagurus excavatus, (B) Anapagurus alboranensis and (C) A. petiti. Solid line (spring/summer) and dashed line (autumn/winter). See text for descriptive equations. 
and in spring/summer (ANCOVA $F=9.305, \mathrm{df}=1$, $P<0.0001)$, and fewer eggs were observed in the former period (Figure 5). The relationships were: autumn/winter $\left(\right.$ eggs $\left.=-38.842+57.975 \mathrm{SL}, \mathrm{N}=74, r^{2}=0.17, P<0.0003\right)$ and spring/summer $\quad($ eggs $=-93.492+108.334 \quad$ SL, $\left.\mathrm{N}=106, r^{2}=0.38, P<0.0001\right)$. The relationship in $A$. petiti was as follows: (eggs $=-230.589+172.739$ SL, $N=19$, $r^{2}=0.474, P=0.003$ ). Minimum (and maximum) sizes of ovigerous females of $A$. alboranensis collected in autunm/ winter and spring/summer were $1.12 \mathrm{~mm}(1.78 \mathrm{~mm})$ and $0.86 \mathrm{~mm}(2.24 \mathrm{~mm})$, respectively. The frequency of ovigerous females reached over $50 \%$ (SM50) for the $1.0 \mathrm{~mm}$ and $0.5 \mathrm{~mm}$ size-classes. Minimum (and maximum) sizes of ovigerous females of $A$. petiti was $1.58 \mathrm{~mm}(3.04 \mathrm{~mm})$, and SM50 was observed for the $1.5 \mathrm{~mm}$ size-class. Pagurus excavatus also showed differences in the maturity size by season. Minimum (and maximum) of specimens collected in autumn/winter and spring/ summer were $3.7 \mathrm{~mm}(7.6 \mathrm{~mm})$ and $5.3 \mathrm{~mm}(8.0 \mathrm{~mm})$ respectively. SM50 were $4 \mathrm{~mm}$ and $6 \mathrm{~mm}$ size-classes, respectively.

\section{DISGUSSION}

Pagurus excavatus is the most abundant and largest species, whereas the two species of Anapagurus are less abundant, although both have a quite similar size range. These differences in size distributions are reflected in the distinct use of shells of various sizes. Pagurus excavatus generally use large shells of Nauticaris hebraeus, which are quite abundant in the area, whereas the two species of Anapagurus and juveniles of $P$. excavatus use those of Turritella spp., among others (unpublished data). Shell preferences and availability are crucial for the coexistence and abundance of hermit crabs (Bertness, 1981; Harvey, 1990) and future studies should consider their influence in the abundance and distribution patterns of the three species considered here.

Pagurus excavatus and A. alboranensis are sexually dimorphic in relation to size, males being larger than females. However, males and females of $A$. petiti reach similar large sizes. Furthermore, the populations of the three species have a female biased sex ratio, although only significantly different in A. petiti. Different authors showed that the sex ratio of most crustacean species differs from 1:1, and in hermit crabs, females are usually more abundant (Manjón-Cabeza \& García-Raso, 1999a; Turra \& Leite, 2000, among others). The size dimorphism has been observed in many decapod species, including hermit crabs, and is attributed to differential growth rates between sexes (Bertness, 1981). These differences have been observed in numerous species of hermit crabs, including $P$. excavatus and $A$. alboranensis, where males are more abundant in larger size-classes and reach larger sizes than females. Males of Calcinus tibicen (Fransozo \& Mantelatto, 1998) are larger than females, which is probably associated with a higher allocation of energy for reproduction or mating success, higher in larger males than in smaller ones (Harvey, 1990). Similar differences have been reported in other hermit crabs belonging to the genus Calcinus, Clibanarius, Dardanus and Diogenes (ManjónCabeza \& García-Raso, 1999a; Turra \& Leite, 2000; Yoshino et al., 2002). The absence of sex dimorphism in
A. petiti could be associated with the low abundance of this species and the necessity of both sexes to compete for the same shells used by A. alboranensis (see Harvey, 1990).

Continuous or seasonal reproductive activities are quite common in hermit crabs. In tropical waters, both seasonal and continuous reproductive periods are frequent, whereas seasonal patterns are more common in temperate ones, mainly with a higher frequency of ovigerous females in warmer seasons (see review by Turra \& Leite, 2000; Wada et al., 2000). Some authors have suggested that competition and/or availability of shells are the most plausible explanation for these patterns (see references cited above). Our results also confirm higher reproductive activity during warmer seasons in the two Anapagurus species, although the presence of ovigerous females of A. alboranensis is also high in other seasons. However, $P$. excavatus showed a decrease in this activity in the spring/summer. Moreover, the clutch size of this species was smaller during spring and summer and females of $P$. excavatus and $A$. alboranensis started reproduction at smaller sizes in autumn/winter than in spring/summer. Peaks in reproductive activity are usually associated with favourable environmental conditions or shell availability (e.g. Bertness, 1981; Lancaster, 1990; Yoshino et al., 2002). These conditions, in any case, should affect the three species considered here in a different way. The adaptive significance of the temporal variation of reproduction is still not clear (Turra \& Leite, 2000) and recently Yoshino et al. (2002) demonstrated that the temporal reproductive patterns within a breeding season of Pagurus filholi was affected by predation and shell species. Mature specimens of $P$. excavatus only used shells of Nauticaris hebraeus, never used by specimens of Anapagurus (and probably juveniles of $P$. excavatus), therefore interspecific competitive interactions should be absent. However, a certain degree of competition for shell use could be expected between both species of Anapagurus, of which mature specimens have similar sizes and use similar shell species (unpublished data).

The seasonal patterns in the abundance of the smallest specimens of Pagurus excavatus, Anapagurus alboranensis and $A$. petiti agree quite well with the reproductive period of these species. Although our sampling method is adequate to collect very small individuals (recruits), the study of the recruitment pattern in decapod crustaceans needs a more intense sampling procedure in time and space (Asakura, 1991). Nevertheless, the recruits of the three species occur in the same habitat as adults, contrasting with results reported by other authors, e.g. some species of the genus Clibanarius (Turra \& Leite, 2000) and Calcinus (Fransozo et al., 1998) occurred in distinct habitats from adults. Some authors have suggested that spatial segregation of larval settlement reduce inter- and intra-specific competition for shells in sympatric hermit crabs (Asakura, 1991; Wada et al., 2000). Therefore, the spatial coexistence between adults and juveniles in the species considered in the present study could suggest a reduced competitive interaction at this stage.

The results of the present study provide a basis for establishing some interesting aspects of the biology in various Mediterranean hermit crab species. Nevertheless, further work is needed to elucidate what additional aspects may influence the distribution and abundance of these species 
(e.g. shell availability, predation). Such information would be a major step forward in our understanding of the structure and dynamics of littoral hermit crab communities.

We thank P. Abelló and A. García-Rubies for helpful comments. We also thank I. Abreu and G. Carreras for research assistance. This research was funded by the Agencia Catalana de l'Aigua.

\section{REFERENCES}

Abelló, P., Garbonell, A. \& Torres, P., 2002. Biogeography of epibenthic crustaceans on the shelf and upper slope off the Iberian Peninsula Mediterranean coasts: implications for the establishment of natural management areas. Scientia Marina, 66, Supplement 2, 183-198.

Asakura, A., 1991. Population ecology of the sand-dwelling hermit crab Diogenes nitidimanus. 4. Larval settlement. Marine Ecology Progress Series, 78, 139-146.

Bertness, M.D., 1981. Pattern and plasticity in tropical hermit crab growth and reproduction. American Naturalist, 117, 754773.

Fransozo, A. \& Mantelatto, F.L.M., 1998. Population structure and reproductive period of the tropical hermit crab Calcinus tibicem (Decapoda: Diogenidae) in the region of Ubatuba, São Paulo, Brazil. Journal of Crustacean Biology, 18, 738-745.

Garcia-Gomez, J., 1994. The systematics of the genus Anapagurus Henderson, 1886, and a new genus for Anapagurus drachi Forest, 1966 (Crustacea, Decapoda, Paguridae). Zoologische Verhandelingen, 295, 1-131.

Harvey, A.W., 1990. Sexual difference in contemporary selection acting on size in the hermit crab Clibanarius digueti. American Naturalist, 136, 292-304.

Ingle, R.W., 1993. Hermit crabs of the northeastern Atlantic Ocean and Mediterranean Sea. An illustrated key. Natural History Museum Publications. London: Chapman \& Hall.
Lancaster, I., 1990. Reproductive and life history strategy of the hermit crab Pagurus bernhardus. Fournal of the Marine Biological Association of the United Kingdom, 70, 129-142.

Macpherson, E., Gordoa, A. \& García-Rubies, A., 2002. Biomass size spectra in litoral fishes in protected and unprotected areas in the northwestern Mediterranean. Estuarine, Coastal and Shelf Science, 55, 777-788.

Manjón-Cabeza, M.E. \& García-Raso, J.E., 1999a. Shell utilization by the hermit crabs Diogenes pugilator (Roux, 1829), Paguristes eremita (Linnaeus, 1767) and Pagurus forbesii Bell, 1845 (Crustacea: Decapoda: Anomura), in a shallow-water community from southern Spain. Bulletin of Marine Science, 65, 391-405.

Manjón-Cabeza, M.E. \& García-Raso, J.E., 1999b. Relative growth of the dominant hermit crabs (Decapoda, Anomura) of detritic bottoms from Southern Spain. Crustaceana, 72, 507-515.

Mura, M. \& Cau, A., 2002. Biologia riproduttiva di Pagurus excavatus (Herbst, 1791) (Crustacea; Paguridae) nel Canale di Sardegna. Biologia Marina Mediterranea, 9, 770-773.

Turra, A. \& Leite, F.P.P., 2000. Population biology and growth of three sympatric species of intertidal hermit crabs in southeastern Brazil. Fournal of the Marine Biological Association of the United Kingdom, 80, 1061-1069.

Wada, S., Kitaoka, H. \& Goshima, S., 2000. Reproduction of the hermit crab Pagurus lanuginosus and comparison of reproductive traits among sympatric species. Fournal of Crustacean Biology, 20, 474-478.

Yoshino, K., Goshima, S. \& Nakao, S., 2002. Temporal reproductive patterns within a breeding season of the hermit crab Pagurus filholi: effects of crab size and shell species. Marine Biology, 141, 1069-1075.

Submitted 28 Fuly 2003. Accepted 4 February 2004. 